\title{
Instructions to Authors
}

Submission procedure. Submission of a paper to European Psychiatry is understood to imply that the data contained therein has not previously been published (except in abstract form) or is being considered for publication elsewhere.

There are no submission or pages charges,

Only submissions in English will be considered. One original plus three copies (one copy set of photographs must be original prints) should be submitted to one of the following five receiving centres according to geographical location:

D PrC BALLUS

Unidad de Psiquiatria

Faculdad de Medicina

Casanova, 143

08036 Barcelona, Spain

Fax: (34) 32546691

Pr M MAJ

Universita di Napoli

1st di Psichiatria

Largo Madonna delle Grazie

80138 Napoli Italy

Fax: (39)81 449938

- Pr JD GUELFI

Clinique de la Faculte

100 , rue de la Sante

75674 Paris Cedex 14 France

Fax: (33) 145658943

Pr CB PULL

Centre Hospitalier de Luxembourg

4, rue Barbie

1210 Luxembourg

Fax: (352)45 8762
D Pr H HEIMANN

Goethestrasse 23

7400 Tubingen Germany

Fax: (49) 7071294141

Pr M ACKENHEIL

Psychiatrische Klinik

und Poliklinik

der Universitat Miinchen

Nussbaumstr 7

8000 Miinchen 2 Germany

Fax: (49) 8951604741

- Pr RM MURRAY

Institute of Psychiatry

De Crespigny Park

London SE5 8AF UK

Fax: (44) 717035796

Dr P BECH

Dept of Psychiatry

Frederiksborg General Hospital

DK-3400 Hillerod Denmark

Fax: (45) 48242016
Deputy Editors

\section{- Dr P BOYER}

Inserm, Clinique des maladies mentales et de l'encephale

100 , rue de la Sante

75014 Paris

Fax: (33) 145658943

- Dr Y LECRUBIER

Hopital de la Salpetriere

Pavilion Clerambault U 302

47, boulevard de PHopital

75651 Paris Cedex 13

Fax: (33) 144239249

Submissions from Eastern Europe should, for the time being, be sent to the Deputy Editors.

Submissions from non European countries can be sent to any of the preceding editors.

Papers that do not conform to the general criteria for publication in European Psychiatry will be returned immediately to authors to avoid unnecessary delay in submission elsewhere.

Organisation of the manuscript. Manuscripts should be typewritten/printed double-spaced with wide margins throughout. Title page, abstracts, tables, legends to figures and reference list should each be provided on separate sheets of paper. The title page should include: the title, the name(s) and af filiation(s) of the author(s), an address for correspondence, and telephone/fax numbers for editorial queries. All original and review articles should include an abstract (a single paragraph of no more than 150 words) and 3-6 key words for abstracting and indexing purposes. For original and review articles, the text should be ordered under the following headings: Introduction, Experimental Procedures, Results, Discussion (may be combined with Results), Conclusions, Acknowledgments (when appropriate), References.

- Short communications should not exceed 1500 words or equivalent space including figures and tables, with abstracts of no more than 50 words. - Letters to the Editor (maximum of 500 words will be processed rapidly and therefore should be sent to the Deputy Editors. To ensure speedy publication, please adhere strictly to the general instructions on style and arrangement; provide only figures and tables suitable for direct reproduction - Illustrations. Photographs should be presented as glossy prints with high contrast. Figures should be completely and consistently lettered, the size of the lettering being appropriate to that of the illustration, taking into account the necessary reduction in size.

Illustrations should be designed to fit either a single column or the full text width. Each illustration should be clearly marked on the reverse side with the name of the author(s), the number of the illustration and its orientation (top).

Colour figures will be included subject to the author's agreement to defray part of the cost.

- Tables. All tables must be cited in the text, have titles and be numbered consecutively with roman numerals. Only horizontal lines should be included, and kept to a minimum.

- References (Harvard System) Authors are responsible for the accuracy of the references. Only published articles and those in press (the journal should be stated) may be included; unpublished results and personal communications should be cited as such in the text. In the text, a reference should be cited by author and date; when there are more than two authors, state the first author's name followed by "et at". References should be arranged alphabetically at the end of the paper and include, in the following order: all authors (surnames followed by initials), year in parentheses, journal title (abbreviated according to the Serial Sources for the Biosis Data Base), volume number, and inclusive page numbers. For a book, the editors' names, book title, publisher and publisher's location should appear before volume and page numbers.

\section{Examples:}

Journal article

Loo H, Rein W, Souche A, Dufour H, Guelfi JD, Malka R, Olie JP (1990) Psychopathological and sociodemographic characteristics of 1231 depressed patients with and without co-existing alcoholism. Psychiatr \& Psychobiol 5, 249-256

Book

Takahashi R, R Flor-Henry P, Gruzelier J, Niwa SI (1987) Dynamics, Laterality and Psychopathology. Elsevier, Amsterdam
Chapter in a book

Pinard G, Tetreault L (1974) Concerning semantic problems in psychological evaluation. In: Psychological Measurements in Psychopharmacology. Modern Problems in Pharmacopsychiatry, Vol 7 (Pichot P, ed) Karger, Basel, 8-22

- Nomenclature. Metric units must be used throughout, laboratory units must be followed by SI units. The generic name of a drug should be used unless the specific trade name of the drug is directly relevant to the discussion.

- Proofs and reprints. One set of proofs will be supplied to the author to check for typesetting accuracy : no changes to the original manuscript will be allowed at this stage. To speed up publication lime, authors should respond as quickly as possible, preferably by fax.

25 free reprints are supplied per contribution. Additional reprints may be ordered at the prices quoted on the order form sent to the corresponding author.

- Copyright. As soon as the article is published, the author is considered to have transferred his rights to the publisher. Requests for reproduction should be sent to the latter. 

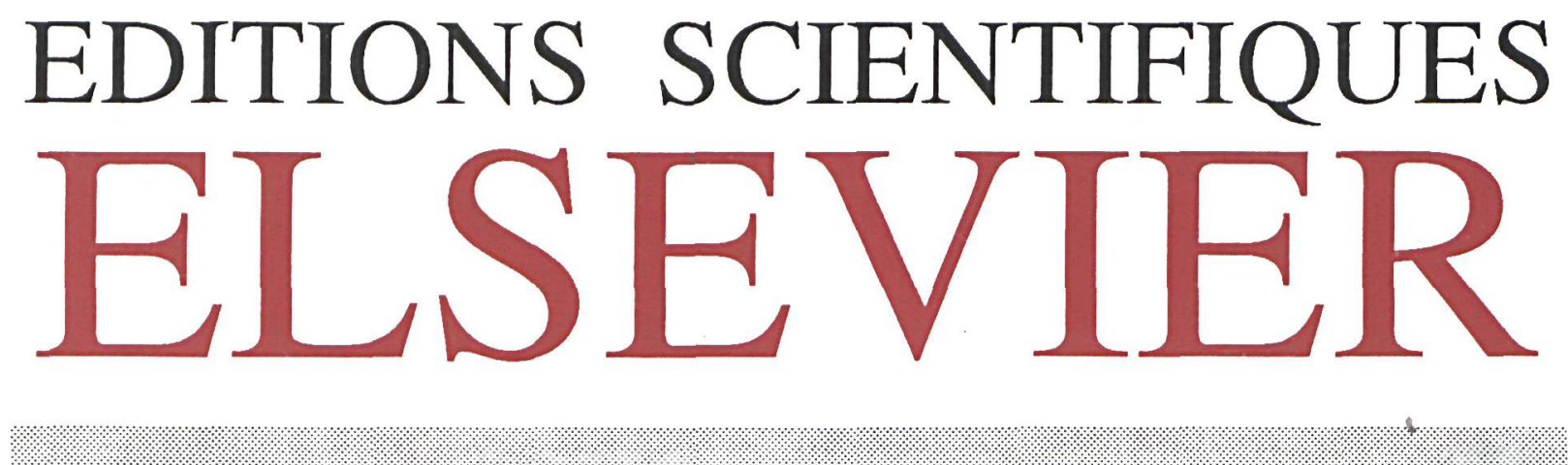

\section{BIO-SCIENCES}

BIOCHIMIE

BIOFUTUR

LE MENSUEL EUROPÉEN DES BIOTECHNOLOGIES

BIOLOGY OF THE CELL

EUROPEAN BIOTECHNOLOGY NEWSLETTER

EUROPEAN JOURNAL OF MEDICINAL CHEMISTRY

FLASHÉTATS-UNIS

FLASH JAPON

FUNDAMENTAL \& CLINICAL PHARMACOLOGY

PUBLICATIONS DE L'INSTITUT PASTEUR:

ANNALES DE L'INSTITUT PASTEUR/ACTUALITÉS

BULLETIN DE L'INSTITUT PASTEUR

RESEARCH IN IMMUNOLOGY

RESEARCH IN MICROBIOLOGY

RESEARCH IN VIROLOGY

\section{BIO-MÉDICAL}

ANNALES DE RÉADAPTATION ET DE MÉDECINE PHYSIQUE BIOMEDICINE \& PHARMACOTHERAPY

BULLETIN DU CANCER

BULLETIN DU CANCER/RADIOTHÉRAPIE

EUROPEANPSYCHIATRY

IMMUNOANALYSE \& BIOLOGIE SPÉCIALISÉE

NEUROPHYSIOLOGIE CLINIQUE

OPTIONBIO

LE JOURNAL DE L'ANALYSE MÉDICALE ET DE LA BIOLOGIE CLINIQUE

PÉDIATRIE

SCIENCE \& SPORTS

THE LANCET ÉDIION FRANÇAISE

URGENCES MÉDICALES

\section{AGRO-SCIENCES}

\section{CHIMIE}

PUBLICATIONS DE LA SOCIÉTÉ FRANÇAISE DE CHIMIE : JOURNAL DE CHIMIE PHYSIQUE ET DE PHYSICO-CHIMIE BIOLOGIQUE

BULLETIN DE LA SOCIÉTÉ CHIMIQUE DE FRANCE

PUBLICATION DE LA SOCIÉTÉ FRANCAISE DE CHIMIE ET DE LA SOCIETÉ DE CHIMIE INDUSTRIELLE

ANALUSIS
PUBLICATIONS DE L'INRA :

AGRONOMIE

ANNALES DE RECHERCHES VÉTÉRINAIRES

ANNALES DES SCIENCES FORESTIÈRES

ANNALES DE ZOOTECHNIE

APIDOLOGIE

GENETICS, SELECTION, EVOLUTION

LE LAIT

REPRODUCTION, NUTRITION, DEVELOPMENT 